\title{
PENGARUH CITRA PERUSAHAAN DAN KUALITAS LAYANAN DENGAN KEPERCAYAAN SEBAGAI VARIABEL MEDIASI
}

\author{
Dellafany Noor Madyaratri \\ Universitas Negeri Surabaya \\ dellafany.17080574051@mhs.unesa.ac.id \\ Anik Lestari Andjarwati \\ Universitas Negeri Surabaya \\ aniklestari@unesa.ac.id
}

Abstract

\begin{abstract}
This paper aimed to study the effect of corporate image and service quality on loyalty by using trust as a mediating variable. This research uses quantitative data. The sampling technique used was non-probability sampling with the type of judgmental sampling). The sample used in this study were 220 respondents. The research method used path analysis--data collection through a questionnaire. The results showed that company image has a positive and significant effect on loyalty, service quality has a positive and significant effect on loyalty, the corporate image has a positive and significant effect on trust, service quality has a positive and significant effect on trust, and trust has a positive and significant effect on loyalty. Kantor Pos Trenggalek is expected to improve the image of Kantor Pos Trenggalek so that customer perception will be better for the services provided and improve and develop the quality of services provided to customers and fix service problems.
\end{abstract}

Keywords: corporate image; loyalty; service quality; trust.

\section{PENDAHULUAN}

Perkembangan industri jasa memegang peranan yang sangat penting dalam perekonomian dunia. Salah satu jenis perusahaan jasa tersebut yaitu perusahaan ekspedisi (Cahyati \& Seminari, 2020). Asosiasi Logistik dan Forwarder Indonesia (ALFI) memprediksi potensi perkembangan bisnis logistik di tanah air mencapai lebih dari 30\% tahun 2020, jika dihitung perkiraan pertumbuhan menyeluruh sebesar Rp40 triliun per tahunnya (Annur, 2019). Dari data indeks kinerja logistik negara Asean, Bank Dunia mencatat indeks performa logistik Indonesia berada pada peringkat 5 dan di level 3,15 dari skala 1 sampai 5 pada tingkat ASEAN (databoks.kadata.co.id, 2019). Seiring dengan banyaknya permintaan masyarakat maupun $e$-commerce yang melakukan pengiriman barang, semakin banyak juga perusahaan jasa kurir yang bermunculan di Indonesia (Abdulwahid, 2019). Sekitar 70\% pelanggan jasa kurir berasal dari pelaku bisnis yang berjualan secara online baik supplier maupun ritel (Nuraeni, 2020).

Perusahaan dituntut memiliki strategi memenangkan persaingan bisnis salah satunya yaitu citra perusahaan (Prabowo et al., 2015). Perusahaan yang memiliki citra positif akan mendorong pelanggan untuk menimbulkan kepercayaan terhadap suatu produk, membeli produk yang ditawarkan, memertinggi kemampuan bersaing, dan akan meningkatkan loyalitas (Istijanto, 2005:185). Rangkuti (2006:44) menyatakan elemen-elemen citra perusahaan yaitu harga yang ditawarkan, reputasi image perusahaan di mata pelanggan, jaminan atas layanan yang berkualitas, penampilan fasilitas fisik, dan komitmen organisasi. Razavi et al. (2012) dan Kaur \& Soch (2013) menyatakan citra perusahaan memiliki pengaruh positif serta signifikan terhadap loyalitas pelanggan. Akan tetapi, Ishaq (2012) mengatakan citra perusahaan tidak memiliki pengaruh signifikan terhadap loyalitas pelanggan.

Semakin banyak jasa kurir yang berdiri, persaingan antara penyedia jasa antaran semakin ketat sehingga dituntut memberikan layanan yang terbaik untuk pelanggannya. Kualitas layanan merupakan salah satu yang dirasakan pelanggan pada saat menggunakan layanan (Cahyati \& Seminari, 2020). Pelanggan dikatakan loyal apabila menujukkan perilaku pembelian secara terus menerus atau mewajibkan pelanggan membeli paling sedikit dua kali dalam kurun waktu tertentu (Griffin, 2016:31). 
Dellafany Noor Madyaratri \& Anik Lestari Andjarwati. Pengaruh Citra Perusahaan dan Kualitas Layanan terhadap Loyalitas dengan Kepercayaan sebagai Variabel Mediasi

Sviokla (1993:115) menyatakan kualitas produk atupun jasa yang diberikan perusahaan dapat menciptakan suatu persepsi positif dari pelanggan terhadap perusahaan serta menghasilkan suatu kepuasan dan loyalitas pelanggan. Fahmi \& Hands (2016) dan Aspizain (2016) mengungkapkan kualitas layanan memiliki pengaruh signifikan terhadap loyalitas pelanggan. Namun Chao, $\mathrm{Wu}, \&$ Yen (2015), dan Sitorus \& Yustisia (2018) mengungkapkan kualitas layanan tidak memiliki pengaruh positif maupun signifikan terhadap loyalitas pelanggan.

Kualitas layanan yang memuaskan, sangat menentukan kepercayaan para pelanggan pada perusahaan (Madjid, 2013). Loyalitas pelanggan dipengaruhi oleh emotional bonding, choice reduction and habit, trust, satisfaction, dan history with company (Zikmund et al., 2003:73). Dalam industri jasa, pengalaman yang mereka rasakan ketika mengonsumsi jasa sangat menjadi perhatian. Jika kepercayaan pelanggan terhadap perusahaan terjalin dengan baik maka akan tercipta loyalitas pada pelanggan (Chuang et al., 2012). Madjid (2013) mengatakan kepercayaan secara langsung memiliki pengaruh positif serta signifikan terhadap loyalitas pelanggan. Selanjutnya Izogo (2018), Chuang et al. (2012), dan Sitorus \& Yustisia (2018) juga mengatakan kepercayaan berpengaruh positif dan signifikan terhadap loyalitas.

PT. Pos Indonesia (Persero) merupakan salah satu perusahaan jasa kurir BUMN dan tertua di Indonesia berdiri tahun 26 Agustus 1746. PT. Pos Indonesia memiliki berbagai layanan terkait jasa kurir yang lebih banyak dibandingkan dengan pesaingnya seperti pos jumbo ekonomi, pos kilat khusus, Q-Comm, Q9 plus, maupun pos express. Selain itu PT. Pos Indonesia memiliki jumlah titik layanan yang sangat luas dan tersebar di seluruh penjuru Indonesia mencapai 58.700 titik dalam bentuk agenpos, Kantor Pos, maupun lainnya (posindonesia.co.id, 2013). Salah satu titik layanan PT. Pos Indonesia yaitu Kantor Pos Trenggalek. Kantor Pos Trenggalek merupakan anak cabang dari Kantor Pos Tulungagung (kantorpos.posindonesia.co.id, 2011). Banyaknya jenis layanan dan jumlah titik layanan yang luas diharapkan dapat memuaskan pelanggan. Market share PT. Pos Indonesia menduduki urutan ke-3 menguasai 9,6\% dari jumlah pasar yang ada (Hidayat, 2020). PT. Pos Indonesia tetap menunjukkan eksistensinya dengan masuk ke dalam Top Brand Award tentang peringkat jasa kurir dari tahun 2018 hingga 2020 dari perusahaan jasa baik dari perusahaan BUMN maupun perusahaan swasta. Penilaian yang diberikan dalam penghargaan ini menilai performa merek diukur melalui tiga indikator PT. Pos Indonesia masuk ke dalam penilaian commitment share. Kriteria penilaian dalam commitment share diperoleh berdasarkan data yang mendorong pelanggan untuk melakukan pembelian di masa mendatang (topbrand-award.com, 2020).

PT. Pos Indonesia berusaha menaikkan pelayanan yang diberikan maupun menggunakan teknologi pada sistem operasionalnya agar dapat melayani generasi ke generasi dalam upaya membangun citra yang baik di mata pelanggan (posindonesia.co.id, 2019). PT. Pos Indonesia dalam peningkatan pelayanan dan pengembangan usaha memerlukan sosialisasi serta publikasi kepada masyarakat agar tetap berada di hati pelanggan (Instragram Pos Indonesia, 2017). PT. Pos Indonesia juga sudah meningkatkan kualitas layanannya untuk mampu bersaing dengan jasa kurir lainnya, seperti melakukan inovasi salah satunya aplikasi Pos Giro Mobile. Selain itu melakukan peluasan jaringan bisnis dengan pengembangan agen pos dan memerbanyak titik layanan hingga di mancanegara (posindonesia.co.id, 2019). Selama pandemi transaksi pengiriman barang e-commerce melalui PT. Pos Indonesia mengalami peningkatan naik sebesar $2 \%$ dibandingkan sebelum pandemi (Kompas.com, 2020).

PT. Pos Indonesia sudah melakukan peningkatan kualitas layanan, namun masih ada komentar buruk terkait pelayanan, salah satunya terkait lambatnya pengiriman paket yang tidak sesuai dengan estimasi waktu yang sudah ditentukan (Riskanora, 2016). Kenaikan komentar buruk dari konsumen terjadi di tahun 2020. Semenjak berlakunya Peraturan Sosial Berskala Besar (PSBB), segala transaksi PT. Pos Indonesia terganggu, khususnya pada pengiriman paket ke luar kota sampai ke luar negeri (Azka, 2020).

Tujuan penelitian yaitu untuk menganalisis dan membahas pengaruh citra perusahaan dan kualitas layanan terhadap loyalitas dengan kepercayaan sebagai variabel mediasi pada pelanggan. 


\section{KAJIAN PUSTAKA DAN PENGEMBANGAN HIPOTESIS}

\section{Citra Perusahaan}

Sutojo (2019:2) mendefinisikan citra perusahaan menjadi salah satu pegangan bagi banyak orang dalam mengambil berbagai keputusan penting seperti membeli barang ataupun jasa yang dihasilkan perusahaan, berlangganan, dan merekomendasikan produk perusahaan kepada orang lain. Kaur \& Soch (2013) mengatakan citra perusahaan merupakan persepsi tentang sebuah perusahaan yang tersimpan dalam ingatan pelanggan. Selanjutnya Razavi et al. (2012) mengemukkan citra perusahaan merupakan kesan keseluruhan yang dibuat oleh seseorang tentang sebuah perusahaan. Dalam mengukur variabel citra perusahaan, indikator yang digunakan merupakan kumpulan dari beberapa penelitian yakni Ishaq (2012) dan Kaur and Soch (2013) meliputi perusahaan yang terkemuka di bandingkan pesaing, perusahaan yang memberikan kesan yang baik melalui iklan dan media lainnya, perusahaan yang memiliki citra positif dibenak para pelanggan, dan perusahaan yang terbuka dan tanggap terhadap pelanggan.

\section{Kualitas Layanan}

Parasuraman et al. (1998) mendefinisikan kualitas jasa merupakan seberapa jauh perbedaan antara kenyataan dengan harapan pelanggan atas layanan yang diterima. Hapsari et al. (2017) mengemukakan kualitas layanan merupakan hasil dari proses evaluasi di mana layanan yang diterima oleh pelanggan dan layanan yang diberikan akan dibandingkan. Kemudian Ishaq (2012) kualitas layanan merupakan penilaian pelanggan secara keseluruhan atas keunggulan penawaran layanan pada sebuah perusahaan yang dipengaruhi oleh kemampuan organisasi untuk memenuhi kebutuhan pelanggan dengan tingkat harapan pelanggan. Dalam mengukur variabel citra perusahaan, indikator yang digunakan merupakan kumpulan dari beberapa penelitian yakni Ishaq (2012), Chuang et al. (2012), dan Hapsari et al. (2017) meliputi jaminan, kepastian (assurance), dan berwujud (tangible).

\section{Kepercayaan}

Sumarwan (2015:166) kepercayaan pelanggan menyangkut kepercayaan bahwa suatu produk memiliki berbagai atribut maupun manfaat berbagai atribut. Atribut produk yaitu karakteristik dari suatu produk. Sitorus \& Yustisia (2018) mengungkapkan kepercayaan konsumen yaitu harapan dari pelanggan terhadap penyedia jasa bahwa secara kredibel dan handal akan memberikan apa yang telah dijanjikan kepada para pelanggan. Lebih lanjut Kaur \& Soch (2013) mengemukakan kepercayaan merupakan penentu utama untuk membangun hubungan antara pelanggan dengan perusahaan. Dalam mengukur variabel citra perusahaan, indikator yang digunakan merupakan kumpulan dari beberapa penelitian yakni Chuang et al. (2012), Madjid (2013), dan Kaur \& Soch (2013) meliputi kemauan untuk menggunakan layanan pada perusahaan tersebut, saya percaya perusahaan memberikan layanan berkualitas dan konsisten, dan saya pikir staf layanan perusahaan dapat dipercaya.

\section{Loyalitas}

Griffin (2016:5) mengungkapkan customer loyalty is defined as non random purchase expressed over time by some decision making unit. Chuang et al. (2012) mengatakan loyalitas merupakan kesediaan pelanggan untuk mengkonsumsi lagi sebuah produk ataupun layanan di masa datang. Sedangkan Chao et al. (2015) loyalitas pelanggan ditunjukkan oleh tindakan berulang sehubungan dengan produk atau layanan pada perusahaan. Indikator yang digunakan untuk mengukur variabel citra perusahaan, mengadopsi Chuang et al. (2012), Kaur \& Soch (2013), dan Ishaq (2012) meliputi: saya merekomendasikan perusahaan kepada siapa saja yang meminta nasihat; saya bersedia membeli kembali produk; dan saya mengganggap perusahaan menjadi pilihan pertama.

\section{Hubungan antar Variabel}

Istijanto (2005:185) mengatakan adapun perusahaan memiliki citra positif untuk menimbulkan kepercayaan terhadap produk, membeli produk yang ditawarkan, mempertinggi kemampuan bersaing, mendorong semangat kerja karyawan, dan meningkatkan loyalitas pelanggan. Razavi et al. (2012) menyebutkan corporate image memiliki pengaruh signifikan terhadap customer loyalty. Selanjutnya Kaur \& Soch (2013) juga menyatakan citra perusahaan (corporate image) memiliki pengaruh yang 
Dellafany Noor Madyaratri \& Anik Lestari Andjarwati. Pengaruh Citra Perusahaan dan Kualitas Layanan terhadap Loyalitas dengan Kepercayaan sebagai Variabel Mediasi

signifikan terhadap loyalitas pelanggan (customer loyalty). Namun Ishaq (2012) menyebutkan corporate image memiliki pengaruh yang tidak signifikan terhadap customer loyalty.

H1: Citra perusahaan positif dan signifikan terhadap loyalitas pelanggan.

Sviokla, (1993:115) kualitas produk ataupun jasa yang diberikan akan menciptakan suatu persepsi positif dari pelanggan terhadap perusahaan serta menghasilkan suatu kepuasan serta loyalitas pada pelanggan. Ishaq (2012) menyatakan kualitas layanan (service quality) memiliki pengaruh signifikan terhadap loyalitas pelanggan (customer loyalty). Selanjutnya Fahmi \& Hands (2016); Aspizain (2016); Izogo (2018); dan Hapsari et al. (2017) menyatakan service quality memiliki pengaruh positif dan signfikan tergadap loyalitas. Namun Basir et al. (2015); Chao et al. (2015); dan Sitorus \& Yustisia (2018) menyatakan service quality tidak berpengaruh signifikan terhadap loyalty.

H2: Kualitas layanan positif dan signifikan terhadap loyalitas pelanggan.

Perusahaan yang memiliki citra yang baik akan mendorong pelanggan untuk menimbulkan kepercayaan terhadap produk, membeli produk yang ditawarkan, mempertinggi kemampuan bersaing, mendorong semangat kerja karyawan dan meningkatkan loyalitas pelanggan (Istijanto, 2005:185). Kaur \& Soch (2013) mengatakan corporate image berpengaruh positif serta signifikan terhadap customer trust. Selanjutnya, Lin and Lu (2010) juga mengatakan corporate image berpengaruh positif dan signifikan terhadap trust.

H3: Citra perusahaan positif dan signifikan terhadap kepercayaan.

Madjid (2013) menyatakan kualitas layanan yang memuaskan sangat menentukan kepercayaan para pelanggan pada perusahaan. Izogo (2018) menyatakan service quality berpengaruh signifikan terhadap customer trust. Selajutnya, Boonlertvanich (2019) juga menyatakan kualitas layanan berpengaruh positif dan signifikan terhadap customer trust.

H4: Kualitas layanan positif dan signifikan terhadap kepercayaan.

Lau \& Lee (1999) faktor kepercayaan pada sebuah merek ialah aspek krusial dalam pembentukan loyalitas merek. Menurut Kaur \& Soch (2013) customer trust memiliki pengaruh signifikan terhadap customer loyalty. Madjid (2013), Izogo (2018), Chuang et al. (2012), dan Sitorus \& Yustisia (2018) juga menyatakan kepercayaan memiliki pengaruh positif dan signifikan terhadap loyalitas.

H5: Kepercayaan positif dan signifikan terhadap loyalitas pelanggan.

Kerangka konseptual yang di gunakan untuk mengetahui pengaruh citra perusahaan dan kualitas layanan terhadap loyalitas dengan kepercayaan sebagai variabel mediasi pada pengunjung Kantor Pos Trenggalek ditunjukkan pada Gambar 1.

\section{METODE PENELITIAN}

Pendekatan dalam penelitian ini merupakan penelitian kausal sedangkan jenis penelitian yaitu konklusif dengan tujuan membuktikan adanya pengaruh dari variabel independen antara lain citra perusahaan dan kualitas layanan terhadap variabel dependen yaitu loyalitas dengan variabel mediasi yaitu kepercayaan kemudian dianalisis secara kuantitatif. Populasi bersifat infinite. Karakteristiknya adalah seseorang yang sudah pernah menggunakan jasa pengiriman paket pada Kantor Pos Trenggalek minimal dua kali dalam satu bulan terakhir. Teknik nonprobability sampling dan menggunakan judgemental sampling diterapkan untuk mengambil sampel yang sesuai dengan karakteristik penelitian ini. Total responden sebanyak 220 responden. Skala likert dipilih sebagai pengukuran penelitian. Pada umumnya skala likert ada 5 tanggapan responden dimulai dari "sangat tidak setuju" hingga "sangat setuju" (Malhotra, 2005:298). Penyebaran kuisioner dilakukan offline 
dengan menyebarkan secara langsung di Kantor Pos Trenggalek. Teknik analisis data Path Analysis (analisis jalur) menggunakan IBM SPSS AMOS versi 26 dan IBM SPSS statistics versi 26.

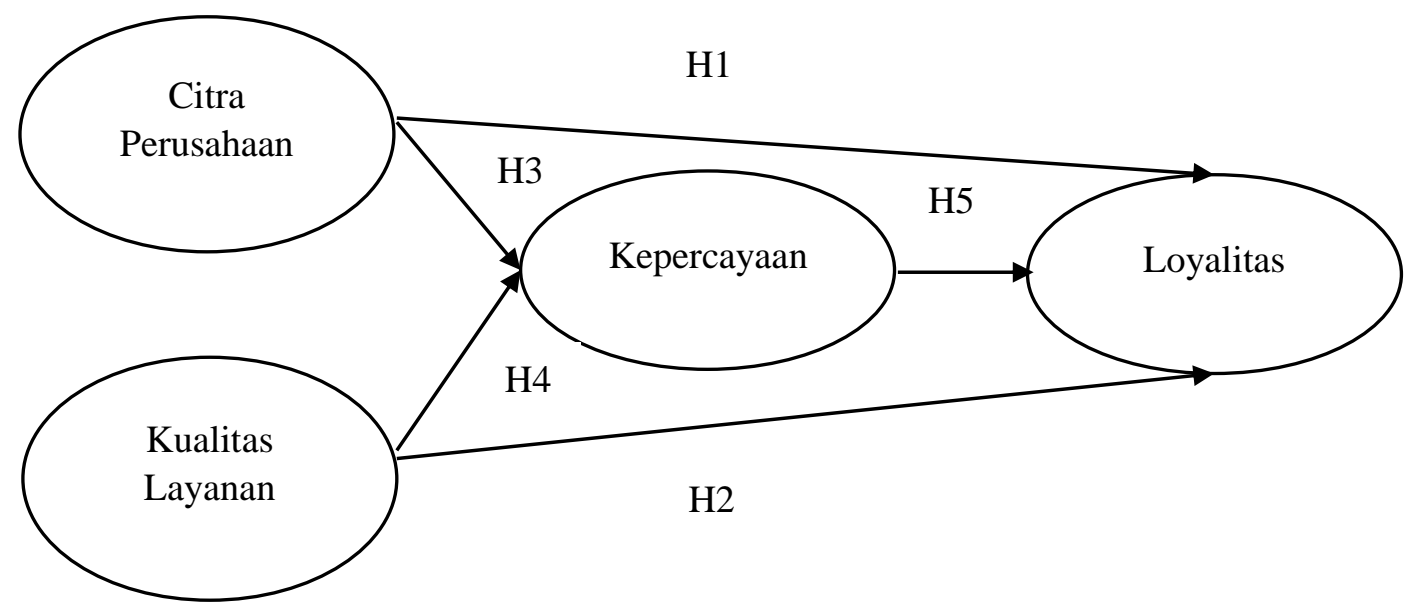

Gambar 1. KERANGKA KONSEPTUAL

\section{HASIL DAN PEMBAHASAN}

\section{Karakteristik Responden}

Jumlah responden yang terlibat dalam pengisian kuisioner penelitian sebanyak 220 responden. Responden dengan frekuensi pengguna jasa pengiriman paket pada Kantor Pos Trenggalek $>2$ kali berjumlah 135 responden atau setara dengan $(61,4 \%)$. Ditinjau dari jenis kelamin di dominasi oleh perempuan berjumlah 111 responden $(50,5 \%)$. Jika ditinjau dari jenis pekerjaan sebagian besar responden sebagai wiraswasta dengan jumlah 52 responden $(23,6 \%)$.

\section{Uji Validitas dan Reliabilitas}

Tabel 1.

HASIL UJI VALIDITAS DAN REABILITAS

\begin{tabular}{cccc}
\hline Variabel & & Corelated Item Total & Cronbach's Alpha \\
\hline Citra Perusahaan $\left(\mathrm{X}_{1}\right)$ & $\mathrm{X}_{1.1}$ & 0,693 & 0,771 \\
& $\mathrm{X}_{1.2}$ & 0,832 & \\
& $\mathrm{X}_{1.3}$ & 0,535 & \\
& $\mathrm{X}_{1.4}$ & 0,753 & 0,721 \\
Kualitas Layanan $\left(\mathrm{X}_{2}\right)$ & $\mathrm{X}_{1.5}$ & 0,563 & \\
& $\mathrm{X}_{2.1 .1}$ & 0,593 & \\
& $\mathrm{X}_{2.1 .2}$ & 0,719 & \\
& $\mathrm{X}_{2.1 .3}$ & 0,711 & \\
& $\mathrm{X}_{2.2 .1}$ & 0,704 & \\
& $\mathrm{X}_{2.2 .2}$ & 0,741 & \\
& $\mathrm{X}_{2.3 .1}$ & 0,596 & \\
Kepercayaan $(\mathrm{Z})$ & $\mathrm{X}_{2.3 .2}$ & 0,801 & \\
& $\mathrm{X}_{2.4 .1}$ & 0,446 & \\
& $\mathrm{Z}_{1.1}$ & 0,407 & 0,733 \\
& $\mathrm{Z}_{1.2}$ & 0,606 & \\
& $\mathrm{Z}_{1.3}$ & 0,687 & \\
Loyalitas (Y) & $\mathrm{Z}_{1.4}$ & 0,738 & \\
& $\mathrm{Y}_{1.1}$ & 0,613 & \\
\hline Sumber: Output SPSS & $\mathrm{Y}_{1.2}$ & 0,619 & \\
& $\mathrm{Y}_{1.3}$ & 0,703 & \\
& & &
\end{tabular}


Dellafany Noor Madyaratri \& Anik Lestari Andjarwati. Pengaruh Citra Perusahaan dan Kualitas Layanan terhadap Loyalitas dengan Kepercayaan sebagai Variabel Mediasi

Tabel 1 hasil uji validitas dan reliabilitas yang dilakukan pada 30 responden di luar dari 220 responden. Berdasarkan hasil uji validitas seluruh item pernyataan variabel citra perusahaan, kualitas layanan, kepercayaan, dan loyalitas menghasilkan $r$ hitung $>0,361$, sehingga dinyatakan valid dan seluruh item variabel dapat lanjutkan sebagai alat ukur dalam penelitian ini. Hasil uji reliabilitas dibuktikan bahwa seluruh item pernyataan dari tiap-tiap variabel memiliki cronbachs alpha bernilai lebih besar dari 0,70 , sehingga diketahui pernyataan yang dibuat dalam instrument adalah reliable dan dapat dilanjutkan sebagai alat ukur.

\section{Uji Kelayakan Model}

Hasil uji kelayakan model diketahui nilai koefisien determinasi kepercayaan $\left(\mathrm{R}^{2}\right)$ sebesar 0,344 dan loyalitas $\left(\mathrm{R}^{2} 2\right)$ sebesar 0,519 . Hasil perhitungan ketepatan model menghasilkan nilai sebesar $68,4 \%$. Hal tersebut mempresentasikan kontribusi model digunakan menjelaskan hubungan sruktural dari empat variabel yang diteliti sebesar $0,684(68,4 \%)$. Sisa hasil tersebut dijelaskan oleh variabel lain di luar model penelitian.

\section{Uji Analisis Jalur}

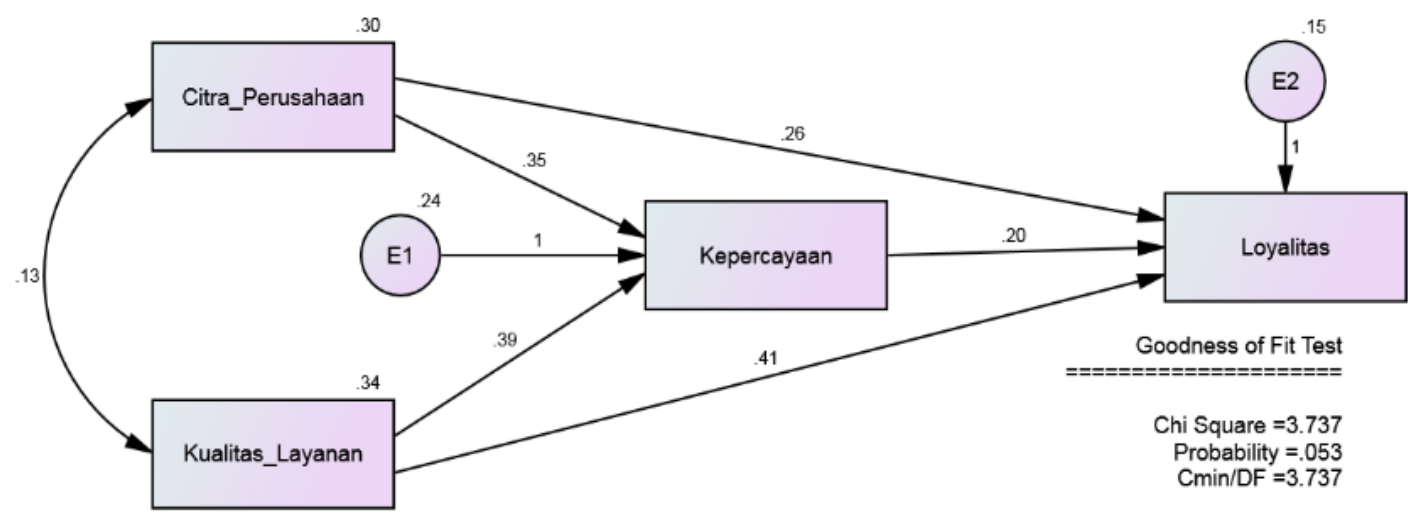

Sumber: Output Amos versi 26 (2021)

\section{Gambar 2. HASIL UJI ANALISIS JALUR}

Gambar 2 dapat dikonversi ke sebuah persamaan model struktural. Menurut Sarwono (2012:38) menghitung nilai dari e1 dan e2 menggunakan rumus e $=\sqrt{ } 1-r^{2}$. Berikut ini merupakan persamaan model struktural (1) dan (2) dari hasil uji analisis jalur.

$\mathrm{Z}=\mathrm{b}_{2} \mathrm{X}+\mathrm{e}_{1}=0,255 \mathrm{X}+0,811$

$\mathrm{Y}=\mathrm{b}_{1} \mathrm{X}+\mathrm{b}_{3} \mathrm{Z}+\mathrm{e}_{2}=0,315 \mathrm{X}+0,210 \mathrm{Z}+0,694$

Tabel 2.

STANDARDIZED REGRESSION WEIGHTS

\begin{tabular}{lc}
\hline \multicolumn{1}{c}{ Hubungan antar Variabel } & Estimate \\
\hline Loyalitas $\leftarrow$ citra perusahaan & 0,255 \\
Loyalitas $\leftarrow$ kualitas layanan & 0,423 \\
Kepercayaan $\leftarrow$ citra perusahaan & 0,315 \\
Kepercayaan $\leftarrow$ kualitas layanan & 0,381 \\
Loyalitas $\leftarrow$ kepercayaan & 0,210 \\
\hline
\end{tabular}

Sumber: Output AMOS versi 26

Tabel 2 menunjukkan terdapat pengaruh positif pada citra perusahaan terhadap loyalitas dengan nilai 0,255. Artinya, semakin tinggi citra perusahaan loyalitas Kantor Pos Trenggalek juga semakin meningkat. Pengaruh positif kualitas layanan terhadap loyalitas bernilai 0,423. Artinya, semakin tinggi kualitas layanan, semakin tinggi loyalitas ke Kantor Pos Trenggalek. Selanjutnya, terdapat pengaruh positif pada citra perusahaan terhadap kepercayaan dengan nilai koefisien jalur 0,315. 
Artinya, semakin tinggi citra perusahaan, semakin tinggi kepercayaan ke Kantor Pos Trenggalek juga. Terdapat pengaruh positif kualitas layanan terhadap kepercayaan dengan nilai 0,381. Artinya. semakin tinggi kualitas layanan, semakin tinggi kepercayaan Kantor Pos Trenggalek. Pengaruh positif pada kepercayaan terhadap loyalitas menghasilkan nilai 0,210. Artinya, semakin tinggi ke Kantor Pos Trenggalek, semakin tinggi loyalitas.

\section{Uji Hipotesis}

Tabel 3.

\section{HASIL UJI HIPOTESIS}

\begin{tabular}{clrlcc}
\hline Hipotesis & Hubungan antar Variabel & Estimate & S.E & C.R & P \\
\hline H1 & Loyalitas $\leftarrow$ citra perusahaan & 0,260 & 0,056 & 4,679 & 0,000 \\
H2 & Loyalitas $\leftarrow$ kualitas layanan & 0,406 & 0,054 & 7,559 & 0,000 \\
H3 & Kepercayaan $\leftarrow$ citra perusahaan & 0,346 & 0,066 & 5,254 & 0,000 \\
H4 & Kepercayaan $\leftarrow$ kualitas layanan & 0,394 & 0,062 & 6,354 & 0,000 \\
H5 & Loyalitas $\leftarrow$ kepercayaan & 0,195 & 0,054 & 3,636 & 0,000 \\
\hline
\end{tabular}

Sumber: Output AMOS versi 26 (2021, data diolah)

Tabel 3 menunjukkan variabel citra perusahaan terhadap loyalitas menghasilkan CR hitung sebesar $4,679 \geq 2,00$ dan nilai probabilitas signifikansinya $0,000(\mathrm{p} \leq 0,05)$. Menyatakan citra perusahaan berpengaruh signifikan terhadap loyalitas diartikan H1 diterima. Selanjutnya, kualitas layanan terhadap loyalitas menghasilkan CR hitung sebesar 7,559 $\geq 2,00$ nilai probabilitas signifikansinya sebesar 0,000 . Menyatakan kualitas layanan berpengaruh signifikan terhadap loyalitas diartikan $\mathrm{H} 2$ diterima. Kemudian, variabel citra perusahaan terhadap kepercayaan menghasilkan CR hitung 5,254 $\geq$ 2,00 nilai probabilitas signifikansinya sebesar 0,000. Melihatkan citra perusahaan berpengaruh signifikan terhadap kepercayaan diartikan $\mathrm{H} 3$ diterima. Lalu, variabel kualitas layanan terhadap kepercayaan menghasilkan CR hitung sebesar 6,354 $\geq 2,00$ nilai probabilitas signifikansinya sebesar 0,000 . Menyatakan kualitas layanan berpengaruh signifikan terhadap kepercayaan artinya bahwa $\mathrm{H} 4$ diterima. Variabel kepercayaan terhadap loyalitas menghasilkan CR hitung sebesar 3,636 2,00 dengan hasil nilai probabilitas signifikansi sebesar 0,000 . Menunjukkan kepercayaan berpengaruh signifikan terhadap loyalitas dan H5 diterima.

\section{Uji Mediasi}

Mediasi secara parsial menjadi hasil akhir dari uji mediasi. Hasil diperoleh karena variabel citra perusahaan dan kualitas layanan terhadap loyalitas signifikan serta variabel tersebut menurun tidak sama dengan 0 namun pengaruhnya akan lebih besar jika melalui variabel $\mathrm{Z}$ (kepercayaan). Hal itu terjadi karena hasil uji mediasi nilai variabel citra perusahaan dan kualitas layanan yang signifikan terhadap loyalitas sebesar 0,197 dan 0,181. Kemudian. variabel citra perusahaan dan kualitas layanan terhadap loyalitas dengan memasukkan variabel kepercayaan menurun sebesar 0,156 dan 0,152 . Jadi semakin tinggi citra perusahaan dan kualitas layanan yang diberikan oleh perusahaan akan memengaruhi kepercayaan pelanggan. Semakin tinggi tingkat kepercayaan yang dirasakan pelanggan, semakin meningkat loyalitas.

\section{Pengaruh Citra Perusahaan terhadap Loyalitas}

Hasil uji menunjukkan terdapat pengaruh citra perusahaan terhadap loyalitas yang positif dan signifikan. Artinya jika sebuah perusahaan memiliki citra positif dibenak para pelanggan maka akan meningkatkan loyalitas. Ini sesuai dengan pernyataan Istijanto (2005:185) perusahaan memiliki citra positif akan mendorong pelanggan untuk memertinggi kemampuan bersaing, membeli produk yang ditawarkan, akan meningkatkan loyalitas pelanggan, dan mendorong semangat kerja karyawan.

Penelitian ini mendukung Razavi et al. (2012) serta Kaur \& Soch (2013) corporate image berpengaruh signifikan terhadap loyalty, akan tetapi tidak mendukung Ishaq (2012) bahwa citra perusahaan memiliki pengaruh tidak signifikan terhadap loyalitas. Terjadinya perbedaan hasil penelitian karena terdapat perbedaan objek penelitian dan indikator. Objek penelitian dari Ishaq 
(2012) yaitu sektor telekomunikasi Pakistan sedangkan objek penelitian ini adalah Kantor Pos Trenggalek. Indikator citra perusahaan dalam penelitian Ishaq (2012) meliputi perusahaan inovatif dan perintis, perusahaan yang terbuka serta tanggap terhadap pelanggan, perusahaan itu cerdas maupun persuasive, perusahaan menjalankan bisnis dengan cara etis, yang terakhir perusahaan itu sukses dan percaya diri. Sedangkan indikator dalam penelitian ini, untuk mengukur variabel citra perusahaan yaitu perusahaan yang terkemuka dibanding pesaing, perusahaan yang memberikan kesan yang baik melalui iklan dan media lainnya, perusahaan yang memiliki citra positif di benak para pelanggan, dan perusahaan yang terbuka dan tanggap terhadap pelanggan.

Kantor Pos Trenggalek meningkatkan pelayanan yang diberikan pada semua bidang layanan dan menggunakan teknologi dalam sistem operasionalnya untuk membangun citra yang baik di mata pelanggan. Berdasarkan jawaban responden indikator pertama dengan pernyataan Kantor Pos Trenggalek menjadi perusahaan yang terkemuka dibanding pesaing adalah jawaban yang tertinggi. Hal tersebut menunjukkan bahwa Kantor Pos Trenggalek memberikan citra yang baik dibenak para pelanggan dan lebih banyak diminati dibandingkan perusahaan jasa kurir lain menjadikan Kantor Pos Trenggalek perusahaan yang terkemuka. Paling mendominasi dalam penelitian ini yaitu responden perempuan dan bekerja sebagai wiraswasta. Responden cenderung menilai perusahaan jasa kurir dengan melihat citra perusahaan yang baik untuk menentukan jasa pengiriman paket yang akan digunakan. Di mana semakin baik citra perusahaan yang diberikan oleh perusahaan, semakin pelanggan akan menjadi loyal dengan melakukan penggunaan kembali jasa pengiriman paket pada Kantor Pos Trenggalek di kemudian hari.

\section{Pengaruh Kualitas Layanan terhadap Loyalitas}

Hasil penelitian membuktikan terdapat pengaruh yang positif dan signifikan antara kualitas layanan terhadap loyalitas. Artinya, apabila perusahaan meningkatkan kualitas layanannya, loyalitas akan meningkat. Ini membuktikan teori Sviokla (1993:115) yang menyatakan kualitas produk ataupun jasa yang diberikan akan menciptakan suatu persepsi positif dari pelanggan terhadap perusahaan serta menghasilkan suatu kepuasan serta loyalitas pada pelanggan.

Hasil penelitian ini mendukung Ishaq (2012) bahwa kualitas layanan (service quality) memiliki pengaruh signifikan terhadap loyalitas pelanggan (customer loyalty) dan juga mendukung Fahmi \& Hands (2016), Aspizain (2016), Izogo (2018), dan Hapsari et al. (2017) yang menyatakan hal serupa. Namun, hasil penelitian ini berbeda dengan Basir et al. (2015), Chao et al. (2015), dan Sitorus \& Yustisia (2018) yang menyatakan service quality tidak berpengaruh signifikan terhadap loyalty. Terjadinya perbedaan hasil penelitian karena perbedaan objek penelitian. Objek penelitian Basir et al. (2015) yaitu jasa transportasi laut. Penelitian Chao et al. (2015) menggunakan objek karaoke pribadi di Taiwan, dan Sitorus \& Yustisia (2018) objek penelitiannya yaitu bank, sedangkan objek yang digunakan dalam penelitian ini adalah Kantor Pos Trenggalek.

Kantor Pos Trenggalek memiliki kualitas layanan yang baik untuk mampu bersaing dengan jasa kurir lainnya seperti bukti fisik (tangibles) Kantor Pos Trenggalek memiliki fasilitas yang lengkap dan nyaman, antara lain yaitu ruang tunggu yang nyaman, parkir yang luas, kamar mandi yang bersih, dan memiliki karyawan ataupun staf yang memiliki kemampuan pengetahuan dan kesopanan. Selain itu, Kantor Pos melakukan berbagai inovasi salah satunya dengan adanya aplikasi Pos Giro Mobile untuk memudahkan pelanggan dalam melakukan semua transaksinya di rumah. Berdasarkan hasil responden indikator empati (empathy) dengan butir pernyataan layanan yang diberikan oleh Kantor Pos Trenggalek memenuhi kebutuhan pelanggan adalah jawaban tertinggi. Hal tersebut dikarenakan Kantor Pos Trenggalek memiliki bermacam-macam layanan terkait pengiriman paket yang sudah memenuhi kebutuan pelanggan seperti layanan pos express, layanan pengiriman pos kilat khusus, layanan pos jumbo ekonomi, dan Q-Comm. Hal ini memungkinkan pelanggan dapat menemukan layanan yang mereka butuhkan terkait jasa pengiriman paket. Responden perempuan dan bekerja sebagai wiraswasta adalah paling mendominasi dalam penelitian ini. Responden cenderung menilai perusahaan jasa kurir dari segi pelayanan yang diberikan untuk menentukan jasa pengiriman paket yang akan digunakan di mana semakin baik kualitas layanan yang diberikan oleh perusahaan jasa 
kurir membuat para pelanggan tetap menggunakan jasa pengiriman paket dikemudian hari dan mendorong pelanggan tetap loyal terhadap Kantor Pos Trenggalek.

\section{Pengaruh Citra Perusahaan terhadap Kepercayaan}

Berdasarkan uji yang telah dilakukan, terdapat pengaruh yang positif serta signifikan antara citra perusahaan terhadap kepercayaan. Artinya, apabila perusahaan memiliki citra positif di benak pelanggan, kepercayaan para pelanggan akan meningkat. Sehingga, hal ini membuktikan konsep Istijanto (2005:185) yang menyatakan perusahaan yang memiliki citra positif mendorong pelanggan untuk menimbulkan kepercayaan terhadap produk, membeli produk yang ditawarkan, dan meningkatkan loyalitas pelanggan. Penelitian ini mendukung Kaur \& Soch (2013) yang menyatakan corporate image berpengaruh positif serta signifikan terhadap customer trust. Selanjutnya, Lin and Lu (2010) juga mengatakan corporate image berpengaruh positif dan signifikan terhadap trust.

Karyawan Kantor Pos Trenggalek memiliki kemampuan dalam membantu pelanggan jika bertanya ataupun complain terkait semua jenis layanan, guna membangun kepercayaan pelanggan,. Selain itu, Kantor Pos Trenggalek memiliki jaminan apabila paket tidak sampai pada pelanggan, hilang, maupun rusak pada saat proses pengiriman. Berdasarkan jawaban responden, indikator kemauan untuk menggunakan jasa pengiriman pada Kantor Pos Trenggalek adalah jawaban tertinggi. Hal tersebut menunjukkan bahwa pelanggan mau untuk menggunakan jasa pengiriman paket pada Kantor Pos Trenggalek tidak di jasa kurir lain. Sebagai contoh, Kantor Pos Trenggalek selalu terbuka terhadap saran dan tanggap terhadap keluhan pelanggan sehingga pelanggan percaya dan tetap menggunakan jasa pengiriman paket di Kantor Pos Trenggalek.

\section{Pengaruh Kualitas Layanan terhadap Kepercayaan}

Hasil pengujian menunjukkan pengaruh yang positif serta signifikan antara kualitas layanan terhadap kepercayaan. Memiliki arti apabila kualitas layanan yang diberikan perusahaan meningkat maka menimbulkan kepercayaan. Hal ini membuktikan penelitian Madjid (2013) kualitas layanan yang memuaskan sangat menentukan kepercayaan para pelanggan pada perusahaan. Penelitian ini mendukung Izogo (2018) service quality berpengaruh signifikan terhadap trust. Selajutnya, Boonlertvanich (2019) juga menyatakan kualitas layanan berpengaruh positif dan signifikan terhadap customer trust.

Kualitas layanan yang baik dari Kantor Pos Trenggalek hal ini akan mendorong para pelanggannya untuk merasakan percaya dari kualitas layanan yang diterima. Sebagai contoh, Kantor Pos Trenggalek selalu melindungi setiap data atau informasi pribadi dari pelanggan, sehingga pelanggan akan menjadi nyaman akan kualitas layanan yang diberikan oleh Kantor Pos Trenggalek. Rasa nyaman tersebut akan membuat pelanggan menjadi percaya akan kualitas layanan yang diberikan oleh Kantor Pos Trenggalek.

\section{Pengaruh Kepercayaan terhadap Loyalitas}

Hasil penelitian membuktikan pengaruh positif serta signifikan antara kepercayaan dengan loyalitas yang dapat diartikan apabila kepercayaan pelanggan meningkat maka akan meningkatkan loyalitas. Ini membuktikan konsep Lau \& Lee, (1999) yang menyatakan faktor kepercayaan terhadap sebuah merek merupakan aspek krusial dalam pembentukan loyalitas merek. Penelitian ini mendukung Kaur \& Soch (2013) yang menyatakan kepercayaan (customer trust) memiliki pengaruh signifikan terhadap loyalitas pelanggan (customer loyalty) serta Madjid (2013), Izogo (2018), Chuang et al. (2012), dan Sitorus \& Yustisia (2018) yang menyatakan hal serupa.

Berdasarkan jawaban responden, pernyataan "saya menganggap Kantor Pos Trenggalek menjadi pilihan pertama" adalah jawaban tertinggi. Hal tersebut dikarenakan Kantor Pos Trenggalek telah menjadi pilihan pertama pelanggan dalam hal jasa pengiriman paket dibanding jasa kurir lain. Responden perempuan dan bekerja sebagai wiraswasta adalah paling mendominasi dalam penelitian ini. Responden cenderung akan merasakan kepercayaan apabila paket yang dikirimkan sampai ditangan penerima tanpa ada masalah pelayanan seperti paket rusak maupun hilang. Oleh karena itu, 
Dellafany Noor Madyaratri \& Anik Lestari Andjarwati. Pengaruh Citra Perusahaan dan Kualitas Layanan terhadap Loyalitas dengan Kepercayaan sebagai Variabel Mediasi

semakin meningkat kepercayaan yang dirasakan pelanggan, semakin berpotensi besar untuk tetap loyal terhadap Kantor Pos Trenggalek.

Berdasarkan hasil uji mediasi dapat dilihat bawa peranan variabel kepercayaan dalam memediasi antara citra perusahaan, kualitas layanan, dan loyalitas memiliki peranan partial mediation. Hasil diperoleh karena variabel citra perusahaan dan kualitas layanan terhadap loyalitas signifikan serta variabel tersebut menurun tidak sama dengan 0 namun pengaruhnya akan lebih besar jika melalui variabel Z (kepercayaan). Dengan demikian maka variabel kepercayaan terbukti mampu memengaruhi antara citra perusahaan, kualitas layanan, dan loyalitas. Membuktikan konsep teori Zikmund et al. (2003:73) kepercayaan (trust) merupakan salah satu variabel yang dapat mempengaruhi loyalitas pelanggan. Selain itu juga mendukung penelitian Madjid (2013) bahwa trust dapat menjadi variabel mediasi.

\section{KESIMPULAN}

Berdasarkan uji yang sudah diteliti kesimpulannya adalah citra perusahaan dan kualitas layanan memiliki pengaruh positif serta signifikan terhadap loyalitas, citra perusahaan dan kualitas layanan memiliki pengaruh positif maupun signifikan terhadap kepercayaan, dan kepercayaan memiliki pengaruh positif dan signifikan terhadap loyalitas. Beberapa kelemahan dalam penelitian yaitu tidak menyediakan pertanyaan terbuka untuk menanyakan asal responden, sehingga tidak dapat mengetahui informasi tentang tempat tinggal responden. Selanjutnya, karakteristik dalam angket yang kurang lengkap, penelitian selanjutnya diharapkan untuk menambahkan karakteristik dalam angket yang disebarkan, seperti usia, penghasilan, pendidikan terakhir, dan karakteristik lainnya untuk menambahkan informasi tentang objek yang diteliti. Setelah itu, peliti menggunakan variabel eksogen yang sudah banyak diteliti oleh peneliti lain. Penelitian selanjutnya, disarankan untuk melakukan penelitian di luar variabel eksogen (citra perusahaan dan kualitas layanan) yang sudah digunakan dan diharapkan memakai variabel baru (seperti variabel perceived value, switching cost, dan customer relationship) yang dapat memengaruhi loyalitas disesuai dengan objek.

Implikasi praktis dari hasil penelitian ini Kantor Pos Trenggalek diharapkan untuk meningkatkan citra dari Kantor Pos Trenggalek agar persepsi pelanggan semakin baik terhadap layanan yang diberikan. Selain itu, Kantor Pos Trenggalek diharapkan dapat meningkatkan maupun mengembangkan kualitas layanan yang diberikan kepada pelanggan dan memperbaiki masalah-masalah layanan seperti keterlambatan pengiriman paket agar pelanggan tetap loyal terhadap Kantor Pos Trenggalek. Sedangkan implikasi teoritis menemukan variabel citra perusahaan dan kualitas layanan memiliki pengaruh terhadap loyalitas, namun pengaruhnya akan lebih besar jika melalui variabel kepercayaan.

\section{DAFTAR PUSTAKA}

Abdulwahid, H. (2019). Perkembangan Globalisasi dengan Adanya Penyedia Jasa Pengiriman Barang. (https://www.kompasiana.com/hilman20/5dfb30a0097f365f020c5ab2/perkembanganglobalisasi-dengan-adanya-penyedia-jasa-pengiriman-barang, diakses pada 10 November 2020)

Annur, C. M. (2019). Prospeknya Cerah, Bisnis Logistik di Prediksi Tumbuh Lebih 30\% di 2020. (https://katadata.co.id/sortatobing/berita/5e9a50d967cca/prospeknya-cerah-bisnis-logistikdiprediksi-tumbuh-lebih-30-di-2020, diakses pada 11 November 2020)

Aspizain, C. (2016). The Effects of Service Quality and Corporate Rebranding. RJOAS, 12(December), 209-217. https://doi.org/10.18551/rjoas.2016-12.26

Azka, R. M. (2020). Dampak Virus Corona, Pengiriman Barang Bakal Telat. (https://ekonomi.bisnis.com/read/20200205/98/1197744/dampak-virus-corona-pengirimanbarang-bakal-telat, diakses pada 10 November 2020)

Basir, M., Modding, B., Kamase, J., \& Hasan, S. (2015). Effect of Service Quality, Orientation 
Services, and Pricing on Loyalty and Customer Satisfaction in Marine Transportation Services. International Journal of Humanities and Social Science Invention, 4(6), 1-6. ISSN (Online): 2319 - 7722, ISSN (Print): 2319 - 7714

Boonlertvanich, K. (2019). Service Quality, Satisfaction, Trust, and Loyalty: The Moderating Role of Main-Bank and Wealth Status. International Journal of Bank Marketing, 37(1), 278-302. https://doi.org/10.1108/IJBM-02-2018-0021

Cahyati, N. K., \& Seminari, N. K. (2020). The Role of Customer Satisfaction in Mediating the Effect of Service Quality and Marketing Experience on Repurchase Intention (Study in PT Pos Indonesia Expedition Services). American Journal of Humanities and Social Sciences Research, 4(2), 128-135. e-ISSN :2378-703X

Chao, R., Wu, T.-C., \& Yen, W.-T. (2015). The Influence of Service Quality, Brand Image, and Customer Satisfaction on Customer Loyalty for Private Karaoke Roomsin Taiwan. The Journal of Global Business Management, 11(1), 59-67.

Chuang, L.-M., Tsai, M.-T., Wu, Z.-X., \& Shiu, J.-J. (2012). The Impact of Customer Interaction on Customer Loyalty in Taiwan's International Tourist Hotels: The Mediating Effect of Service Quality and Trust. Innovative Marketing, 8(2), 33-45.

Databoks.kadata.co.id. (2019). Di Tingkat ASEAN, Daya Saing Logistik Indonesia Peringkat ke 5. (https://databoks.katadata.co.id/datapublish/2019/03/08/di-tingkat-asean-daya-saing-logistikindonesia-peringkat-ke-5, diakses pada 10 November 2020)

Fahmi, A., \& Hands, D. (2016). Impact of Service Quality, Price, and Brand on Loyalty with the Mediation of Customer Satisfaction on Pos Ekspres in East Java Mohamad. Mediterranean Journal of Social Sciences MCSER Publishing, 7(4), 2039-9340. https://doi.org/10.5901/mjss.2016.v7n4p

Griffin, J. (2016). Customer Loyalty. Jakarta: Erlangga.

Hapsari, R., Clemes, M. D., \& Dean, D. (2017). The Impact of Service Quality, Customer Engagement, and Selected Marketing Constructs on Airline Passenger Loyalty. International Journal of Quality and Service Sciences. https://doi.org/10.1108/IJQSS-07-2016-0048

Hidayat, D. (2020). Optimisme Bisnis Jasa Kurir di Masa Pandemi. (https://infobrand.id/optimismebisnis-jasa-kurir-di-masa-pandemi.phtml, diakses pada 11 November 2020)

Ishaq, I. (2012). Perceived Value, Service Quality, Corporate Image, and Customer Loyalty: Empirical Assessment from Pakistan. Serbian Journal of Management, 7(1), 25-36. https://doi.org/10.5937/sjm1201025i

Istijanto. (2005). Riset Sumber Daya Manusia. Jakarta: PT. Gramedia Pustaka Utama.

Izogo, E. E. (2018). Customer Loyalty in Telecom Service Sector: The Role of Service Quality. The TQM Journal, 29(1), 19-36. https://doi.org/10.1108/TQM-09-2015-0115

Kantorpos.posindonesia.co.id. (2011). Kantor $\quad$ Pos $\quad$ Trenggalek. (http://kantorpos.posindonesia.co.id/unitlayananposlist, diakses pada 10 November 2020)

Kaur, H., \& Soch, H. (2013). Mediating Roles of Commitment and Corporate Image in the Formation of Customer Loyalty. Journal of Indian Business Research, 5(1), 33-51. https://doi.org/10.1108/17554191311303376 
Dellafany Noor Madyaratri \& Anik Lestari Andjarwati. Pengaruh Citra Perusahaan dan Kualitas Layanan terhadap Loyalitas dengan Kepercayaan sebagai Variabel Mediasi

Kompas.com. (2020). PT Pos Indonesia Catat Kenaikan Pengiriman Barang E-commerce Selama Pandemi. (https://money.kompas.com/read/2020/07/14/140437326/pt-pos-indonesia-catatkenaikan-pengiriman-barang-e-commerce-selama-pandemi, diakses pada 11 November 2020)

Lau, G. T., \& Lee, S. H. (1999). Consumer's Trust in a Brand and the Link to Loyalty. Journal of Market-Focused Management, 4, 341-370.

Lin, L.-Y., \& Lu, C.-Y. (2010). The Influence of Corporate Image, Relationship Marketing, and Trust on Purchase Intention: the Moderating Effects of Word-of-Mouth. Tourism Review, 65(3), 1634. https://doi.org/10.1108/16605371011083503

Madjid, R. (2013). Customer Trust as Relationship Mediation Between Customer Satisfaction and Loyalty at Bank Rakyat Indonesia ( BRI ) Southeast Sulawesi. The International Journal of Engineering And Science, 2(5), 48-60. ISSN(e): 2319 - 1813 ISSN(p): 2319 - 1805

Malhotra, K. N. (2017). Riset Pemasaran (Edisi 4). Jakarta: PT. Indeks Kelompok Gramedia.

Nuraeni. (2020). Jasa Logistik Melesat di Era e-Commerce. Kominfo.Go.Id. (https://kominfo.go.id/index.php/content/detail/6707/Jasa+Logistik+Melesat+di+Era+eCommerce+/0/sorotan_media, diakses pada 12 November 2020)

Parasuraman, A. P., Zeithaml, V. A., \& Berry, L. L. (1998). SERVQUAL: A Multiple Item Scale for Measuring Consumer Perceptions of Further Research. Journal of Retailing, 64, 1.

Posindonesia.co.id. (2013). Layanan Pengiriman Paket pada PT. Pos Indonesia. (https://www.posindonesia.co.id/id, diakses pada 11 November 2020)

Posindonesia.co.id. (2019). Transformasi Pos Indonesia. (https://www.posindonesia.co.id/en, diakses pada 11 November 2020)

Prabowo, Y., Prihatini, A., \& Prabawani, B. (2015). Pengaruh Citra Perusahaan dan Kualitas Pelayanan Terhadap Keputusan Penggunaan Jasa Pengiriman Paket PT. Pos Indonesia (Studi Pada Kantor Pos Johar Kota Semarang). Jurnal Ilmu Administrasi Bisnis S1 Undip, 4(2), 394399.

Ramadhani, N. (2020). Ini Dampak Perkembangan Teknologi yang Dapat Dirasakan. (https://www.akseleran.co.id/blog/perkembangan-teknologi/, diakses pada 12 November 2020)

Rangkuti, F. (2006). Riset Pemasaran. Jakarta: PT. Gramedia Pustaka Utama.

Razavi, S. M., Safari, H., Shafie, H., \& Vandchali, H. R. (2012). How Customer Satisfaction, Corporate Image and Customer Loyalty are Related? European Journal of Scientific Research, $78(4), 588-596$.

Riskanora, A. (2016). Keluhan Pengiriman Pos Indonesia. (https://www.lapor.go.id/laporan/detil/keluhan-pengiriman-pos-indonesia, diakses pada 12 November)

Sarwono, J. (2012). Path Analysis untuk Riset Skripsi, Tesis, dan Disertasi. Jakarta: Elex Media Kumpotindo.

Sitorus, T., \& Yustisia, M. (2018). The Influence of Service Quality and Customer Trust toward Customer Loyalty: The Role of Customer Satisfaction. International Journal for Quality Research, 12(3), 639-654. https://doi.org/10.18421/IJQR12.03-06 
Sumarwan, U. (2015). Perilaku Konsumen (Edisi 2). Bogor: Ghalia Indonesia.

Sutojo, S. (2019). Membangun Citra Perusahaan. Jakarta: Damar Mulia Pustaka.

Sviokla, J. J. (1993). Keeping Customers. Nevada: Harvard Business Riview Book.

Tjiptono, F. (2014). Pemasaran Jasa. Yogyakarta: Andi.

Topbrand-award.com. (2020). Top Brand Index Jasa Kurir Indonesia. (https://www.topbrandaward.com/en/2020/06/jasa-kurir-fase-2-2020/, diakses pada 11 November 2020)

Zikmund, W. G., JR, M. R., \& Gilbert, F. W. (2003). Integrating Marketing Strategy and Information Technology. New Jersey: John Wiley and Sons. 